\title{
The last food mile concept as a city logistics solution for perishable products
}

\section{The case of Parma's Food Urban Distribution Center}

Eleonora Morganti

SPLOTT, IFSTTAR

Cité Descartes, 14-20 Boulevard Newton

77447 Marne-la-Vallée cedex 02, France

eleonora.morganti@ifsttar.fr

\author{
Jesus Gonzalez-Feliu \\ LET, CNRS \\ ISH, 14 Avenue Berthelot \\ 69363 Lyon Cedex 07, France \\ jesus.gonzalez-feliu@cnrs.fr
}

\begin{abstract}
This paper analyzes last mile logistics for fresh food products and the food deliveries schemes to urban food outlets, i.e. corporate retail chains, independent retailers and hotel, restaurants and catering (Ho.Re.Ca.) sector. We present two concepts: that of food hub and that of last food mils, as well as an analysis framework to understand food last mile distribution. To illustrate it, two experiences of urban food distribution are compared to a reference situation using the proposed framework.
\end{abstract}

\section{Résumé}

Cet article analyse la logistique du dernier kilomètre pour les produits frais, dans les différents secteurs impliqués, i.e. grande distribution organisée, commerces indépendants et secteur de la restauration. Nous présentons deux concepts : celui du pole alimentaire et celui du dernier kilomètre alimentaire, ainsi qu'un cadre d'analyse pour comprendre la distribution alimentaire en ville. Pour l'illustrer, deux expériences de logistique alimentaire urbaine sont comparés à une situation de référence, en utilisant la méthode proposée.

Keywords: food hub, last food mile, urban distribution center (UDC), city logistics, profession knowledge.

Mots-clé: pôle alimentaire, dernier kilomètre alimentaire, centre de distribution urbaine (CDU), logistique urbaine, connaissance métier.

\section{Introduction}

City logistics incorporates the "last mile" or "final mile" of the freight delivery journey, identified as the small scale distribution of goods in urban environment. This part of the freight transport system is often the most expensive because of a high diversity of stakeholders, each with specifics aims, the scarcity of space, and a multiplication and constraints that make difficult to have economies of scale so have an impact on both delivery costs and environmental nuisances. Indeed, the resulting scenario is a variety of vehicles circulating within the city without co-ordination.

This paper aims to present the concept of last food miles, mainly in the case of city logistics, as well as an analysis framework to compare urban distribution centers (UDC) for fresh foods deliveries. First we propose an overview on food hubs and present the main concepts of last food mile logistics. Second, we propose an analysis framework based on a set of indicators, referred to a standard initial situation. Finally, we illustrate the framework by 
comparing two cases od food deliveries systems, that of Parma and that of Padua, both in Italy.

\section{Last food mile logistics and food hubs in city logistics}

A renovation in the traditional wholesale produce market is observed around Europe (). New organizational concepts are now discussed by researchers under the model known as regional and/or alternative food hubs $(\mathrm{FH})$, defined as "partnership based arrangements that coordinate the distribution of a range of food products from producers of a uniform provenance to conventional or hybrid markets" (Morley et al., 2009). They can be developed at existing supply chain infrastructures playing a new or renewed role as alternative intermediaries, at wholesalers' level, at retailers' level, or can take the forms of public sector initiative, producer cooperatives or producer-entrepreneur partnerships. At a logistics level, the FH core components are: (1) Aggregation/ Distribution - Wholesale , (2) Active coordination and (3) Permanent facilities.

Moreover, successful wholesaling requires a good balance between small-scale and largescale suppliers and a diverse mix of customers to provide the best marketing option for each product (Morganti, 2011a). As the supply base continues to consolidate, alliances must be built with large national and regional supply organizations while at the same time, relationships must be maintained with small, high quality producers. Among the WPM customers, there is a growing number of retail chains. Servicing the supermarkets requires a high level of quality assurance, supply planning, transport, logistics and business management. By contrast, servicing the independent stores requires attention to detail and developing good personal relationships, and logistics service too.

There are crucial components such as marketing, organizational and technical elements which determine the performance of the wholesale market at both commercial and logistics levels. Going further in this double function perspective, the FH should be able to integrate logistic urban networks and to provide services to achieve a high degree of collection in the goods flows, in order to supply efficient transport from the market area to the city centre. By doing so, the FH can play the logistics role of urban distribution center for food products (it can be only fruit and vegetables, potentially, for other food and non- food products), having as principal advantage the alleviation of local environmental and traffic concerns in urban areas by increasing in the load factors of commercial vehicles dedicated to food deliveries.

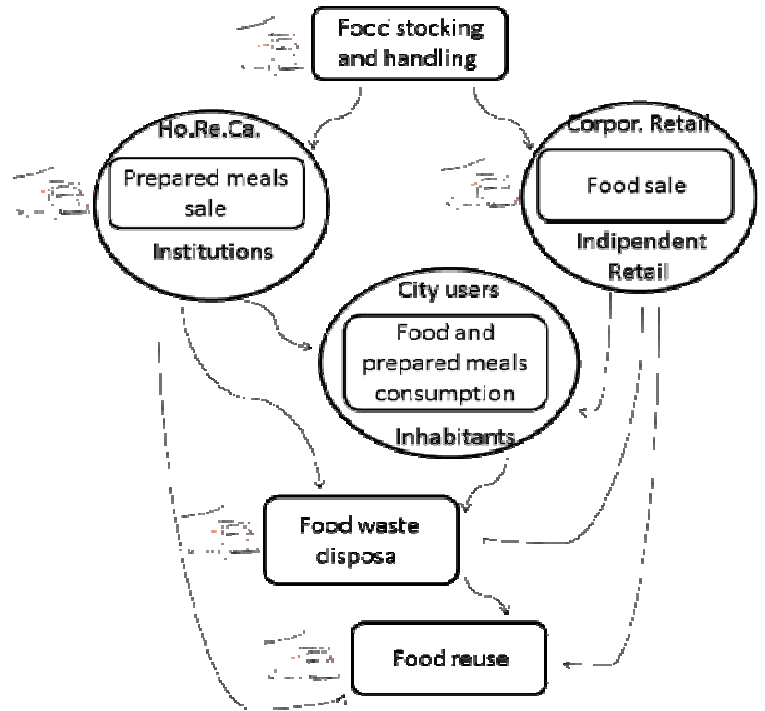

Figure 1. The urban food flow - Focus on transport activities (Morganti, 2011b) 
At different phases of the urban distribution system, logistics and transport implement and control the forward flows of food products and related information between the point of origin and the point of destination. The figure 1 shows the main processes of the urban food chain and the related transport functions operated by commercial vehicles: from local warehouses, wholesalers and suppliers facilities foodstuffs are transported to urban food retailing and catering operators (corporate and independent retailers, Ho.Re.Ca., institutional food services and business canteens), so-called "last mile" logistics. Then, additional transport operations are needed from food outlets to the landfill and to the food reuse site.

Within a food miles analysis (Pirog et al. 2001; Pirog, 2004), we investigate only the final part of the food supply chain delivery and we identify the environmental impact caused by urban food transport, in terms of air pollutants. For this purpose, we adopt the concept of "last food mile" (Morganti, 2011), being an expression combines the last mile and food miles concepts, and we use it in the study to facilitate the comprehension of the research. Last food mile logistics refers them to "the physical distribution of food occurring in the last part of food supply chain". (Morganti, 2011). It concerns then the final delivery of perishable goods to urban food outlets. This concept includes logistics criteria related to the efficient and effective distribution schemes, related to the economic, environmental and social sustainability of urban communities. It usually consists in small deliveries managed by transport operators and suppliers, wholesalers and distributors, and also, as self-provisioning operation, by shop owners and food retailers.

\section{The proposed analysis framework}

The urban food distribution scheme is different according to the type of supply chain it relates with. In this study, we focus on the "last mile" logistics, notably for retailing, often consists of light goods vehicles (LCV) deliveries taking place over short distances, reconciling many customers and a variety of shipments. The "last mile" is one of the most important yet problematic parts of the supply chain due to two facts: (1) the small scale distribution of goods in urban environment is the least efficient part of the supply chain due to the high atomization of receivers and to their increasing requirements, and (2) the high degree of "empty running" implies extra costs. As LCVs perform a greater proportion of their vehicle trips and vehicle kilometers in urban areas than HGVs, they make a greater contribution to urban congestion than HGVs. Operations involving de-consolidation from a few HGVs to many LCVs at urban distribution centers (UDCs) because of traffic restriction on HGVs may result in worsening urban congestion.

To describe this complex scenario related to urban food transport, we focus on selected components characterizing city logistics and perishable goods logistics processes, on the basis of the technical guidelines issued by the Regione Emilia Romagna, Mobility and Transport Department (Rosini, 2005). According to them, there are logistics, technological, organizational variables characterizing the performance of city logistics, as described in table 1 . 
Table 1. City logistics variables set (Morganti 2011)

\begin{tabular}{|c|c|c|}
\hline Categories & Variables & Details \\
\hline \multirow{3}{*}{ Logistics variables } & Frequency & delivery frequency \\
\hline & Load unit & $\begin{array}{l}\text { shape in which the goods are usually grouped and } \\
\text { loaded on vehicles (pallet, roll, box, etc.) }\end{array}$ \\
\hline & Delivery features & $\begin{array}{l}\text { number of deliveries /trip, } \\
\text { weight of each delivery }\end{array}$ \\
\hline \multirow{4}{*}{$\begin{array}{l}\text { Technological and } \\
\text { organizational variables }\end{array}$} & Typology of vehicles & dimensions and technical features of the vehicles \\
\hline & Delivery period & $\begin{array}{l}\text { period of the day in which the delivery of the } \\
\text { goods is usually carried out }\end{array}$ \\
\hline & $\begin{array}{l}\text { Level of logistics } \\
\text { optimization }\end{array}$ & $\begin{array}{l}\text { capacity utilization of the vehicle (in weight and/or } \\
\text { volume) }\end{array}$ \\
\hline & Carriers typology & $\begin{array}{l}\text { on own account, self provisioning, third party } \\
\text { logistics }\end{array}$ \\
\hline
\end{tabular}

\section{Results}

To make a comparison among urban food hubs, we propose to compare the two main examples of fresh food urban distribution systems to a reference. The reference is obtained from Morganti and Gonzalez-Feliu's (2014) results, by agregating the main characteristics of routes for last food mile deliveries (including all types of carriers on the same category). Data from Parma's UDC is adapted from Morganti's (2011a,b) analyses. For Padua's UDC, which is part of a global service involving food and non-food deliveries, data has been obtained from Gonzalez-Feliu and Morana (2010), Morana and Gonzalez-Feliu (2011) and Vaghi and Percoco (2011) with data for fresh food obtained by a phone interview with the manager of the system. We present in Table 2 the different variables for each case:

Table 2. City logistics variables for the three considered cases

\begin{tabular}{|c|c|c|c|c|}
\hline Categories & Variables & Reference & Parma's UDC & Padova's UDC \\
\hline \multirow{4}{*}{$\begin{array}{l}\text { Logistics } \\
\text { variables }\end{array}$} & Frequency & 1.8 times/day & Once/day & Once/day \\
\hline & Load unit & Pallet, parcel & Pallet/parcel & Parcel \\
\hline & Num. deliveries/trip & $\begin{array}{l}1,6 \text { hypermarkets } \\
4 \text { other stores }\end{array}$ & $\begin{array}{l}1 \text { hypermarkets } \\
18 \text { other stores }\end{array}$ & $\begin{array}{l}12 \text { (no hypermar- } \\
\text { ket deliveries }\end{array}$ \\
\hline & Weight/delivery & $150 \mathrm{~kg}$ & $160 \mathrm{~kg}$ & $100 \mathrm{~kg}$ \\
\hline \multirow{4}{*}{$\begin{array}{l}\text { Technological } \\
\text { and } \\
\text { organizational } \\
\text { variables }\end{array}$} & Types of vehicles & $\begin{array}{l}\text { Diesel, different } \\
\text { sizes }\end{array}$ & Gas, 3.5T & Gas, 3.5T \\
\hline & Delivery period & $\begin{array}{l}\text { Morning (peak } \\
\text { hour: } 6 \text { a.m.) }\end{array}$ & 6 a.m.-1 p.m. & $\begin{array}{l}9 \text { a.m.-1 p.m. } \\
2 \text { p.m.-6 p.m. }\end{array}$ \\
\hline & Loading rate & Under $50 \%$ & More than $80 \%$ & About $70 \%$ \\
\hline & Carriers typology & $\begin{array}{l}\text { Mainly } \\
\text { account }\end{array}$ & Third party & Third party \\
\hline
\end{tabular}

We observe that Parma's UDC, which has been developed at a food hub and targeting both grocery distribution and Ho.Re.Ca. stakeholders, has characteristics closer to the reference, in terms of logistics variables. However, we observe a high level of optimization, due to the flow rationalisation. Indeed, Parma's UDC delivers near 20 customers in a route, where reference routes serve in average about 4 customers per route. This is due to the dominance of own account, which is one of the main targets of Parma's UDC (not only Ho.Re.Ca. but also supermarkets, which present important parts of own account in Italy). Padua's platform is not a food hub, but a classical logistics facility operational since 2004 that has included food delivery services since 2010. Their market is restricted and their main customers are small shops and Ho.Re.Ca., so their performance is lower than that of Parma or that of non-fresh products but remains higher than that of classical food distribution.

Note that similar systems can also be found in other wholesales produce markets, like that of Paris-Rungis, which goal is not to sustainably deliver the city but to offer a complementary service to customers (mainly Ho.Re.Ca. establishments) that prefer to be delivered instead of traveling to buy themselves their required fresh food products. The system is operational and 
has important economic benefits, is based on a total supply at wholesalers located in Rungis $\mathrm{FH}$, taking advantage of the synergies that this type of infrastructure can develop.

\section{Conclusion}

In this paper we have presented the concepts of food hub and last food mile, as well as an analysis framework to define the main characteristics of last food miles with and without urban consolidation-based food hubs. We compared a reference situation with the results of two UDCs (one being a food hub, the other not). We observe that food hubs, when used as UDCs, are more adapted to food distribution and present a high potential in terms of optimization. However, this notion is new and needs to be improved. Further analysis of environmental performance and comparison with other types of food hubs are needed to complete and expand this work.

\section{References}

Gonzalez-Feliu, J., Morana, J., "Are City Logistics Solutions Sustainable? The Cityporto case", TeMA. Journal of Land Use, Mobility and Environment, 3 (2), 2010, pp. 55-64.

Morana, J., Gonzalez-Feliu, J., "Le transport vert de marchandises : l'expérience de la ville de Padoue en Italie», Gestion : Revue Internationale de Gestion, 36 (2), 2011, pp. 16-24.

Morganti, E., Urban food planning, city logistics and sustainability: the role of the wholesale produce market. The cases of Parma and Bologna food hubs, Ph.D. Thesis, 2011a, Alma Mater Studiorum - University of Bologna, Italy.

Morganti, E., "Urban food planning and transport sustainability: A case study in Parma, Italy". Proceedings of European Association of Agricultural Economists, EAAE 4th PhD Workshop, April 2011b.

Morganti, E., Gonzalez-Feliu, J., City logistics for perishable products. The case of the Parma Food Hub. Technical Report LET, 2014. Submitted to Case Studies in Transport Policy.

Morley, A., Morgan, S., Morgan, K., Food hubs: The 'missing middle' of the local food infrastructure, Technical Report, 2009, BRASS Centre, Cardiff University.

Pirog, R. Food miles: a simple metaphor to contrast local and global food systems. Hunger And Environmental Nutrition (HEN), Dietetic Practice Group, American Dietetic Association, Summer 2004.

Pirog, R., Van Pelt, T., Enshayan, K., Cook, E., Food, Fuel, and Freeways, Technical Report, 2001, Leopold Center for Sustainable Agriculture, Iowa State University, Ames.

Rosini, R., ed., City Ports Project. Intermediary report. Quaderni del servizio Pianificazione dei Trasporti e Logistica, Regione Emilia Romagna, 2011, Bologna, Italy.

Vaghi, C., Percoco, M., "City logistics in Italy: success factors and environmental performance". In Macharis, C., Melo, S. (eds.), City distribution and urban freight transport. Multiple perspectives, Emerald, Northampton, 2011, pp. 151-175. 